\title{
GENESIS OF INCEPTISOLS ON A VOLCANIC LANDSCAPE IN TAIWAN
}

\author{
Zuens-Sans Chen', Tsuns-Chens Tsou', Victor B. Asio', and Chen-Chi Tsai ${ }^{1}$
}

Very little data are available regarding the genesis of Inceptisols derived from pyroclastic materials in Taiwan because most of the earlier research focused on Andisols. This study was conducted to explain the formation of Inceptisols derived from the pyroclastic material in northern Taiwan. Three pedons representing the summit, backslope, and footslope positions of a volcanic landscape were examined and sampled for physical, chemical, and mineralogical analyses. Results revealed that the soils were moderately developed and characterized by an A-BA-Bw-BC horizon sequence, loam to clay loam texture, firm and subangular blocky structure, low bulk density, high water, and $\mathrm{P}$ retention. The soils were very acid, with low exchangeable bases but very high exchangeable $\mathrm{Al}$ as well as considerable amounts of $\mathrm{Al}$ associated with humus. Gibbsite and quartz were found to be dominant in the sand fraction, whereas gibbsite, kaolinite, and 2:1 minerals were the major minerals in the clay fraction. Formation of the soils was relatively fast because of the easy weatherability of the pyroclastic materials, perhumid climate, and good drainage of the volcanic landscape. Since these Inceptisols possessed several Andic soil features, we hypothesize that they probably developed from earlier formed Andisols. Therefore, it is likely that the sequence of soil formation was Entisol $\rightarrow$ Andisol $\longrightarrow$ Inceptisol. The most important soil-forming processes in the formation of the Inceptisols were likely structure formation, loss of bases and acidification, braunification, bioturbation, organic matter accumulation, weathering, and clay mineral formation. (Soil Science $2001 ; 166: 255-266$ )

Key words: Inceptisols, Andisols, volcanic landscape, Andic soil features, sequence of soil formation, Entisols.

\footnotetext{
SOIL formation theory indicates that a specific $\checkmark$ combination of the soil-forming factors climate, parent material, organism, topography, and time produces a particular kind of soil (Jenny, 1941). For instance, in many countries around the Pacific basin, young pyroclastic materials on well drained landscapes covered with forest or grass vegetation and under humid climates favor the formation of Andisols (Shoji et al., 1993; ISSS Working Group RB, 1998). Such a combination of soil-forming factors occurs in the late Pleis-

'Department of Agricultural Chemistry, National Taiwan University, Taipei 106-17, Taiwan ROC. Dr. Chen is correspondins author. E-mail:soilchen@ccms. ntu.edu.tw.

2Institute of Tropical Ecology, Visayas State College of Agriculture, Baybay, Leyte 6521-A, Philippines.

Received Aus 4, 2000; accepted Dec. 12, 2000.
}

tocene-Holocene volcanic landscapes of northern Taiwan, resulting in the widespread occurrence of Andisols (Huang and Chen, 1990; Chen and Huang, 1991; Chen et al., 1999). However, our extensive survey revealed that Inceptisols also occur on several mountain slopes where Andisols are expected to be found. Although the close association of Andisols and Inceptisols is generally accepted (Parfitt et al., 1983; Hewitt and Witty, 1988; Shoji et al., 1993; ISSS Working Group RB, 1998), very little research has been conducted that elucidates the formation of Inceptisols from young pyroclastic materials. Thus, it is not clear how Inceptisols develop from such materials, although it could be the effect of limited leaching, drainage, and artificial compaction (Hewitt and Witty, 1988).

Inceptisols are soils that have undergone modifications of the parent material by soil-forming 
processes that are sufficient to distinguish them from Entisols but not intense enough to form the diagnostic horizons that are required for classifying them into other soil orders (Foss et al., 1983). They are formed on practically all major types of parent materials, ranging in age from old to young, which makes them relatively less understood compared with the other soil orders. Foss et al. (1983) also reported that the Inceptisol is the "garbage can" of Soil Taxonomy. Consequently, Inceptisols include an assemblage of soils with contrasting genesis and properties, and it is, therefore, important to provide more information about this soil order. Buol et al. (1997) noted that although these soils offer unique opportunities to assess the weathering of relatively easily weatherable minerals and to understand better the initiation of many pedogenic processes, few pedogenic studies have been directed to Inceptisols. Likewise, we also emphasized in a previous paper (Chen et al., 1999) that the genesis of volcanic soils in Taiwan is still poorly understood, and, hence, more research is needed in this area of pedology.

Inceptisols derived from pyroclastic materials such as those selected in this study may have formed following two pathways: (i) through the Entisol $\rightarrow$ Inceptisol sequence, implying that the Inceptisols developed directly from Entisols; and (ii) through the Entisol $\rightarrow$ Andisol $\rightarrow$ Inceptisol sequence, which means that the Inceptisols have passed through the Andisol stage. We are not aware of any detailed study dealing with the first sequence, whereas the second sequence has been observed in New Zealand (Parfitt et al., 1983) and the Philippines (Otsuka et al., 1988).

This study was conducted to explain the formation of Inceptisols derived from pyroclastic material on a volcanic landscape in northern Taiwan. In particular, we gave special attention to the factors and processes that formed the soils classified as Inceptisols.

\section{MATERIALS AND METHODS}

\section{Study Area}

The study area is located in Huangtzuei Mountain in northern Taiwan $\left(25^{\circ} 10^{\prime} \mathrm{N}\right.$, $121^{\circ} 35^{\prime} \mathrm{E}$ ), which is part of the Yangmingshan National Park (Fig. 1). Elevation in the area ranges from 700 to about $1000 \mathrm{~m}$, and slope varies from $<5$ to $>60 \%$. The geology is characterized by late-Pleistocene andesitic pyroclastic material rich in amphibole and pyroxene erupted about 0.5 million years B.P. (Chen, 1990). Based on our field observations and previous research (Asio and Chen, 1998; Chen et al., 1999), how-
(A)
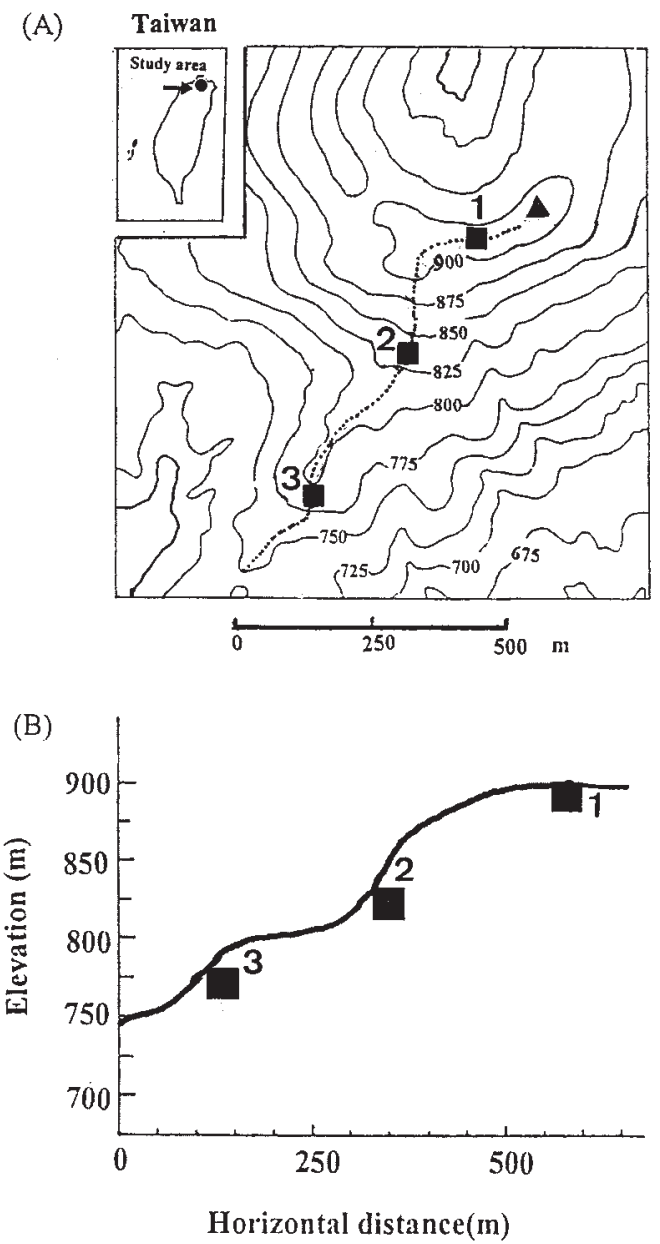

Fig. 1. The location of three soil pedons in the study area and a diagram showing their landscape positions along the elevation transect.

ever, we believe, that much younger (Holocene) volcanic deposits of almost the same geochemistry as the late-Pleistocene material blanketed the mountain range from which are derived the young volcanic soils widespread in the area. There is no evidence that the parent material in this study area may be aeolian (loess) (Chen, 1990). Climatic seasonal records for the mountain from 1943 to 1990 reveal an average annual rainfall of $4800 \mathrm{~mm}$, average temperature of 16.6 ${ }^{\circ} \mathrm{C}\left(\min .=14.3{ }^{\circ} \mathrm{C}, \max =19.7^{\circ} \mathrm{C}\right)$, and average relative humidity of $92 \%$. The soil moisture and temperature regimes in the study area are perudic and thermic, respectively (Soil Survey Staff, 1998). The natural vegetation cover is predominantly Persea thunbergii and Smilax taiheiensis in the lower slopes and Miscanthus floridulus, Eurya crenatifolia, and Axonopus compressus in the upper 
slopes. No evidence of cultivation was observed, indicating that the soils are relatively pristine.

\section{Field Soil Description and Sampling}

Three pedons representing the summit, backslope, and footslope positions along a toposequence were examined and sampled (Fig. 1). At each landscape position, we examined two to three soil pedons to select one representative and specific site for this study. Profile description was carried out according to standard procedure (Soil Survey Staff, 1993). Representative bulk soil samples were collected from the horizon of each pedon, air dried, gently crushed to pass a $2-\mathrm{mm}$ sieve, and used for the analysis of physical, chemical, and mineralogical properties.

\section{Laboratory Analyses}

Bulk density was determined by oven drying the core samples overnight at $105{ }^{\circ} \mathrm{C}$, and particle density was determined by the pycnometer method (Schlichting et al., 1995). Particle-size analysis was performed by the pipette method after dispersion with $0.5 \mathrm{~mol} / \mathrm{L} \mathrm{NaOH}$ at $\mathrm{pH} 10$ combined with vigorous stirring and shaking for 8 h (Hamazaki and Paningbatan, 1988). Moisture retention at 33 and $1500 \mathrm{kPa}$ tensions was determined by pressure membrane apparatus (Klute, 1986). Soil $\mathrm{pH}$ was measured potentiometrically in water and $1 \mathrm{~mol} / \mathrm{L} \mathrm{KCl}$ using a soil:solution ratio of $1: 1$ and in $1 \mathrm{~mol} / \mathrm{L} \mathrm{NaF}$ using a soil:solution ratio of 1:50. Organic $\mathrm{C}$ was analyzed following the Walkley-Black method (Nelson and Sommers, 1982). Potential cation exchangeable capacity $\left(\mathrm{CEC}_{7}\right)$ and exchangeable $\mathrm{Ca}, \mathrm{Mg}, \mathrm{K}$, and $\mathrm{Na}$ were extracted by ammonium acetate at $\mathrm{pH}$ 7.0, and exchangeable Al was extracted by displacement with $1 \mathrm{~mol} / \mathrm{L} \mathrm{KCl}$ (Thomas, 1982). Effective cation exchange capacity (CECef) was calculated as the sum of exchangeable $\mathrm{Ca}, \mathrm{Mg}, \mathrm{K}$, $\mathrm{Na}$, and $\mathrm{Al}$; base saturation percentage (BS \%) using the formula BS \% = (Sum of exch. $\mathrm{Ca}, \mathrm{Mg}$, $\mathrm{K}$, and $\mathrm{Na}) / \mathrm{CEC}_{7} \times 100 \%$; and aluminum saturation percentage (Alsat \%) by the formula Alsat $(\%)=($ exch. Al/CECef $) \times 100 \%$. Iron, Al, and $\mathrm{Si}$ were extracted by the citrate-bicarbonatedithionite (CBD) procedure (Mehra and Jackson, 1960) and abbreviated as $\mathrm{Fe}_{\mathrm{d}}, \mathrm{Al}_{\mathrm{d}}$, and $\mathrm{Si}_{\mathrm{d}}$, respectively; acid ammonium oxalate at pH 3.0 (Schwertmann, 1964) for $\mathrm{Fe}_{\mathrm{o}}, \mathrm{Al}_{\mathrm{o}}$ and $\mathrm{Si}_{\mathrm{o}}$; and sodium pyrophosphate at $\mathrm{pH} 10$ (McKeague, 1967) for $\mathrm{Fe}_{\mathrm{p}}$ and $\mathrm{Al}_{\mathrm{p}}$. Exchangeable cations as well as $\mathrm{Fe}$, $\mathrm{Al}$, and $\mathrm{Si}$ from selective dissolution analyses were determined by atomic absorption spectrometry (Hitachi, 180-30 type). Phosphate retention was evaluated by the method of Blakemore et al. (1981)

X-ray diffraction (XRD) was performed on oriented clay samples on glass slides and on sand powder samples using a Rigaku CN-2005-type $\mathrm{X}$-ray diffractometer with $\mathrm{Cu}-\mathrm{K}$ alpha radiation, $30-\mathrm{kV}$ accelerating potential, and $10-\mathrm{mA}$ tube current. Saturation and heat treatments of oriented clay samples were performed following standard methods outlined by Whittig and Allardice (1982). Allophane content was estimated from $\mathrm{Si}_{\mathrm{o}}$ multiplied by 5,6 , and 7 for $\mathrm{Al} / \mathrm{Si}$ ratios of about 1.0,1.5, and 2.0, respectively (Parfitt and Wilson, 1985; Parfitt and Kimble, 1989; Parfitt, $1990)$, Ferrihydrite by the formula $\left(\mathrm{Fe}_{\mathrm{o}}-\mathrm{Fe}_{\mathrm{p}}\right) \times$ 1.7 (Childs et al., 1991), and goethite by the formula $\left(\mathrm{Fe}_{\mathrm{d}}-\mathrm{Fe}_{\mathrm{o}}\right) \times 1.6$ (Jahn, 1988).

\section{RESULTS AND DISCUSSION}

\section{Morphology and Physical Characteristics}

Table 1 shows that all three soils in the different landscape positions have generally comparable soil morphology. They all exhibited an A-BA-Bw-BC horizon sequence with a solum thickness ranging from $70 \mathrm{~cm}$ in the summit to $130 \mathrm{~cm}$ at the footslope. The soils had a color hue of $7.5 \mathrm{YR}$ to $10 \mathrm{YR}$ and a texture ranging from loam in the A horizons to clay loam in the Bw horizons. All three pedons showed granular and very friable A horizons as a result of the high organic matter content. The $\mathrm{B}$ horizons of the soils were characterized by angular blocky structure and were firm, slightly plastic, and slightly sticky. Fine and very fine roots and biopores were abundant in the upper horizons of all three soils. Boundaries between the $\mathrm{A}$ and the $\mathrm{B}$ horizons were generally clear. Table 2 indicates that the soils contained moderate amounts of clay and silt, which varied from about 340 to $460 \mathrm{~g} / \mathrm{kg}$ and 340 to $550 \mathrm{~g} / \mathrm{kg}$, respectively, in the solum. Although the $\mathrm{Bw}$ horizons appeared more clayey in the field, this was not shown by the laboratory analysis. Sand was relatively low (100-300 g/kg) and was composed mostly of fine and very fine fractions. This kind of particle size distribution reflects the fast rock weathering confirmed in the area by our previous study (Asio and Chen, 1998). Bulk density of pedons 1 and 3 (except below $70 \mathrm{~cm}$ in pedon 3) was lower than the 0.9 $\mathrm{Mg} / \mathrm{m}^{3}$ required for the Andic soil properties defined in Soil Taxonomy (Soil Survey Staff, 1998). A low bulk density value in pedon 2 was observed only in the A horizon, not in the lower part of the profile. Total porosity of the soils was 


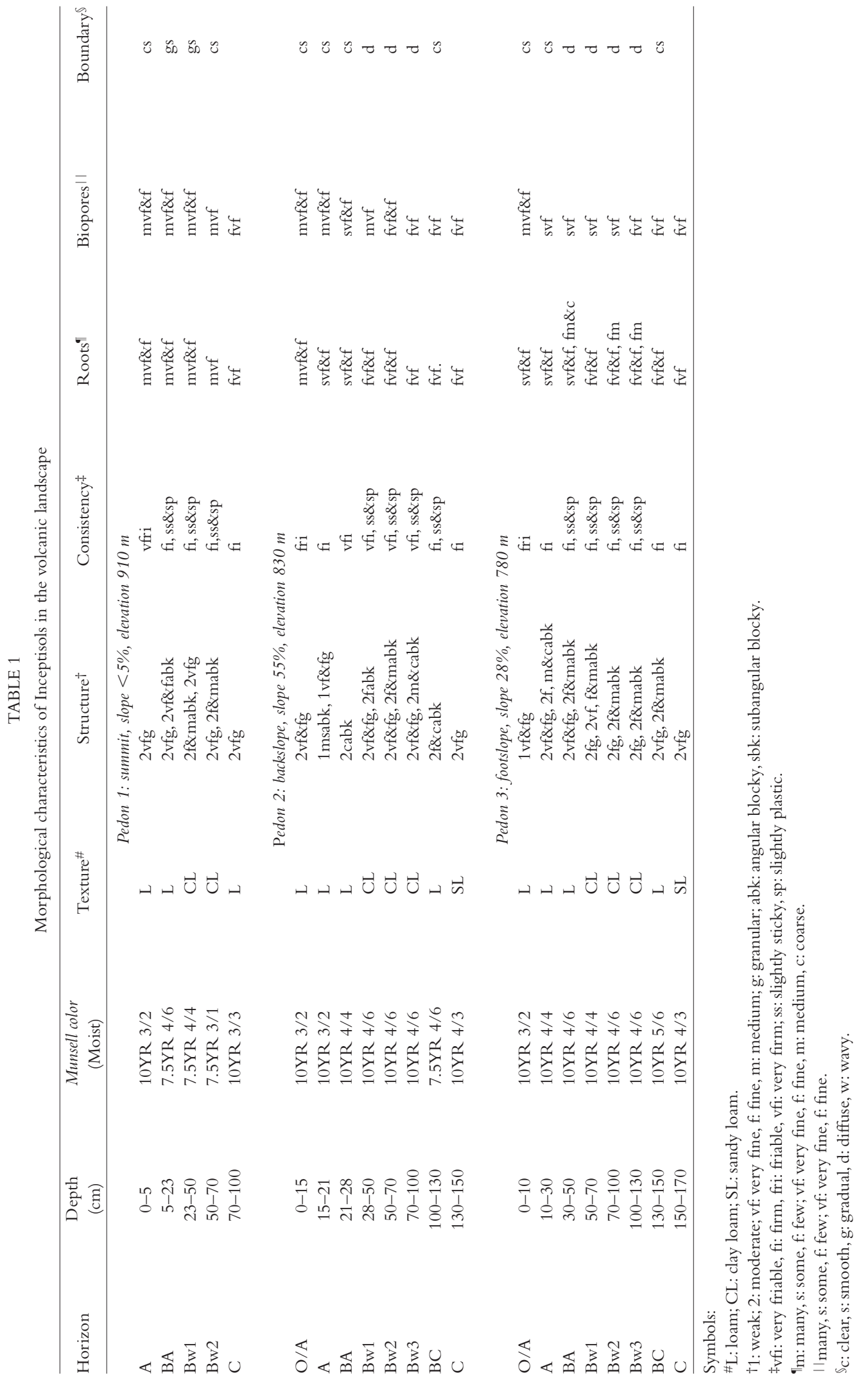


VOL. $166 \sim$ No. $4 \quad$ GENESIS OF INCEPTISOLS ON A VOLCANIC LANDSCAPE

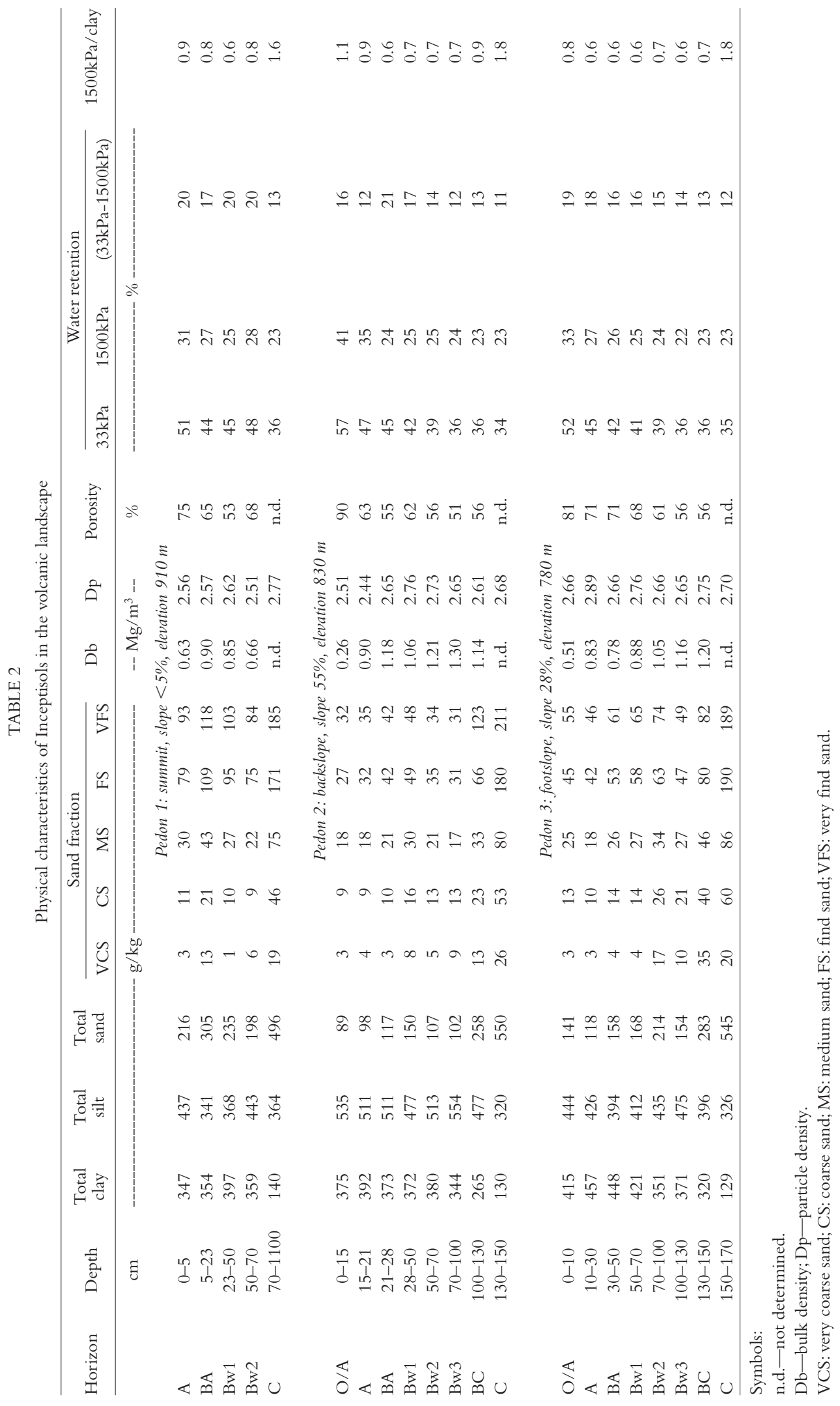


very high, ranging from 75 to $90 \%$ in the A horizons and from 50 to $70 \%$ in the Bw horizons. This could be attributed to high inter- and intraaggregate voids caused by the high organic matter content and isovolumetric weathering (Miehlich, 1991; Chen et al., 1999). Water retention was high at both $33 \mathrm{kPa}(36-50 \%)$ and at $1500 \mathrm{kPa}$ (20-40\%), resulting in an average available water for the three soils of only $16 \%$. The above morphological and physical characteristics of the soils indicate a moderate stage of soil development, which is characteristic of Inceptisols. In addition, the high porosity and friability reflect the contribution of high degree of organic matter and amorphous soil constituents, as is typical of young volcanic soils, particularly Andisols (Shoji et al., 1993).

\section{Chemical Characteristics}

Table 3 shows the chemical characteristics of the three pedons. All soils were strongly to moderately acid, as indicated by a $\mathrm{pH}\left(\mathrm{H}_{2} \mathrm{O}\right)$ ranging from 3.9 to 5.0 . and by a $\mathrm{pH}(\mathrm{KCl})$ varying from 3.6 to 4.7 . In most horizons, the $\mathrm{pH}(\mathrm{NaF})$ ranged from 8.0 to 9.0 , which was slightly lower than the 9.5 value considered an indicator of andic soil materials (FAO, 1998). Organic C was also very high in the A horizons (77 to $99 \mathrm{~g} / \mathrm{kg}$ ) which can be attributed to the resistance of metal-humus complexes to microbial attack (Shoji et al., 1993) and, possibly, to extreme Al toxicity and $\mathrm{P}$ deficiency which limit microbial activity (Chen et al., 1999). Exchangeable bases (K, Na, $\mathrm{Ca}, \mathrm{Mg}$ ) were at a low level resulting in a very low base saturation of less than $10 \%$. In contrast, exchangeable $\mathrm{Al}$ was high $(>2 \mathrm{cmol}(+) / \mathrm{kg})$, especially in the upper part of soil profiles; this explains the very high Al saturation of the soils (70-90\%). Potential cation exchange capacity was low $(<20$ $\mathrm{cmol}(+) / \mathrm{kg})$, but it was almost two-fold higher than the effective cation exchange capacity, which showed values of $<10 \mathrm{cmol}(+) / \mathrm{kg}$. That $\mathrm{CEC}_{7}$ was higher $(\mathrm{pH} 7.0)$ compared with CECef indicates the development of significant amounts of negative charge not actually present in the colloids at field $\mathrm{pH}$. Phosphate retention of the soils was high, having a value of more than $85 \%$ (the value required for the Andic soil property) for most horizons in pedons 1 and 3, but it was slightly below $85 \%$ in pedon 2 .

\section{Mineralogical Characteristics}

Table 4 presents the results of selective dissolution analyses of $\mathrm{Fe}, \mathrm{Al}$, and $\mathrm{Si}$ by dithionite $\left(\mathrm{Fe}_{\mathrm{d}}\right.$, $\left.\mathrm{Al}_{\mathrm{d}}, \mathrm{Si}_{\mathrm{d}}\right)$, oxalate $\left(\mathrm{Fe}_{\mathrm{o}}, \mathrm{Al}_{\mathrm{o}}, \mathrm{Si}_{\mathrm{o}}\right)$, and pyrophosphate $\left(\mathrm{Fe}_{\mathrm{p}}, \mathrm{Al}_{\mathrm{p}}\right)$. It shows only minor differences in these chemical parameters among the three soils. $\mathrm{Fe}_{\mathrm{d}}$ was relatively high, ranging from 16 to 42 $\mathrm{g} / \mathrm{kg}$ in the three pedons, and was much higher than $\mathrm{Fe}_{\mathrm{o}}(4-14 \mathrm{~g} / \mathrm{kg})$ and $\mathrm{Fe}_{\mathrm{p}}(2-12 \mathrm{~g} / \mathrm{kg})$. Moreover, $\mathrm{Fe}_{\mathrm{d}}$ was much higher than $\mathrm{Al}_{\mathrm{d}}$, which reflects the relative instability and greater weathering rates of ferromagnesian minerals as well as the formation of $\mathrm{Fe}$ and $\mathrm{Al}$ forms not extracted by dithionite (Dahlgren et al., 1997). $\mathrm{Al}_{\mathrm{d}}$, which was generally low $(10 \mathrm{~g} / \mathrm{kg})$, seemed to increase in the middle part of the profile. $\mathrm{Al}_{\mathrm{d}}$ was also higher than $\mathrm{Al}_{\mathrm{o}}(6.5 \mathrm{~g} / \mathrm{kg})$ and $\mathrm{Al}_{\mathrm{p}}(7.7 \mathrm{~g} / \mathrm{kg})$ in all three soils.

The ratio of $\mathrm{Fe}_{\mathrm{p}}$ to $\mathrm{Fe}_{\mathrm{o}}\left(\mathrm{Fe}_{\mathrm{p}} / \mathrm{Fe}_{\mathrm{o}}\right)$ was close to 1.0 in most horizons, suggesting that the noncrystalline forms of $\mathrm{Fe}$ are largely associated with humus. Similarly, the ratio of $\mathrm{Al}_{\mathrm{p}}$ to $\mathrm{Al}_{\mathrm{o}}$ $\left(\mathrm{Al}_{\mathrm{p}} / \mathrm{Al}_{\mathrm{o}}\right)$ was more than 1.0 , particularly in the upper horizons, indicating that free $\mathrm{Al}$ is also largely associated with humus. The value of $\mathrm{Al}_{\mathrm{o}}+1 / 2 \mathrm{Fe}_{\mathrm{o}}(\%)$ was more than $1 \%$ in most horizons although still lower than the 2\% required for the Andic soil property in all horizons (Soil Survey Staff, 1998). Amounts of $\mathrm{Si}_{\mathrm{d}}$ and $\mathrm{Si}_{\mathrm{o}}$ were generally low in all soils, and no major differences between the soils were observed. This result implies high desilication of the soils due to weathering and leaching. Table 4 also shows the estimated amounts of ferrihydrite, goethite, and allophane. Only goethite was found to be present in considerable amounts, ranging from about 20 to more than $50 \mathrm{~g} / \mathrm{kg}$.

Table 5 shows the result of XRD analysis of the sand fraction. Quartz and gibbsite were the minerals detected most abundantly in all three soils, with the former found in slightly greater quantity than the latter. Quartz has probably resulted from the weathering of the andesitic parent material (Chen et al., 1999), whereas gibbsite probably originated as feldspar pseudomorphs from the dissolution of feldspar (Asio, 1996; Jahn and Asio, 1998) and may also come from the transformation of halloysite and allophane (Torrent and Benayas, 1977). Minor amounts of cristobalite, pyroxene, amphibole, and feldspar were also detected, reflecting the mineralogical composition of the andesitic pyroclastic material. These minerals seemed to be greater in the lower horizons than in the upper horizons, probably because the lower horizons were relatively less weathered.

Results of XRD analysis of oriented clay samples revealed that kaolinite was the most abundant clay mineral in the clay fraction, followed by $2: 1$ clay minerals such as illite, chlorite, and hydroxy-interlayered vermiculite (HIV) 


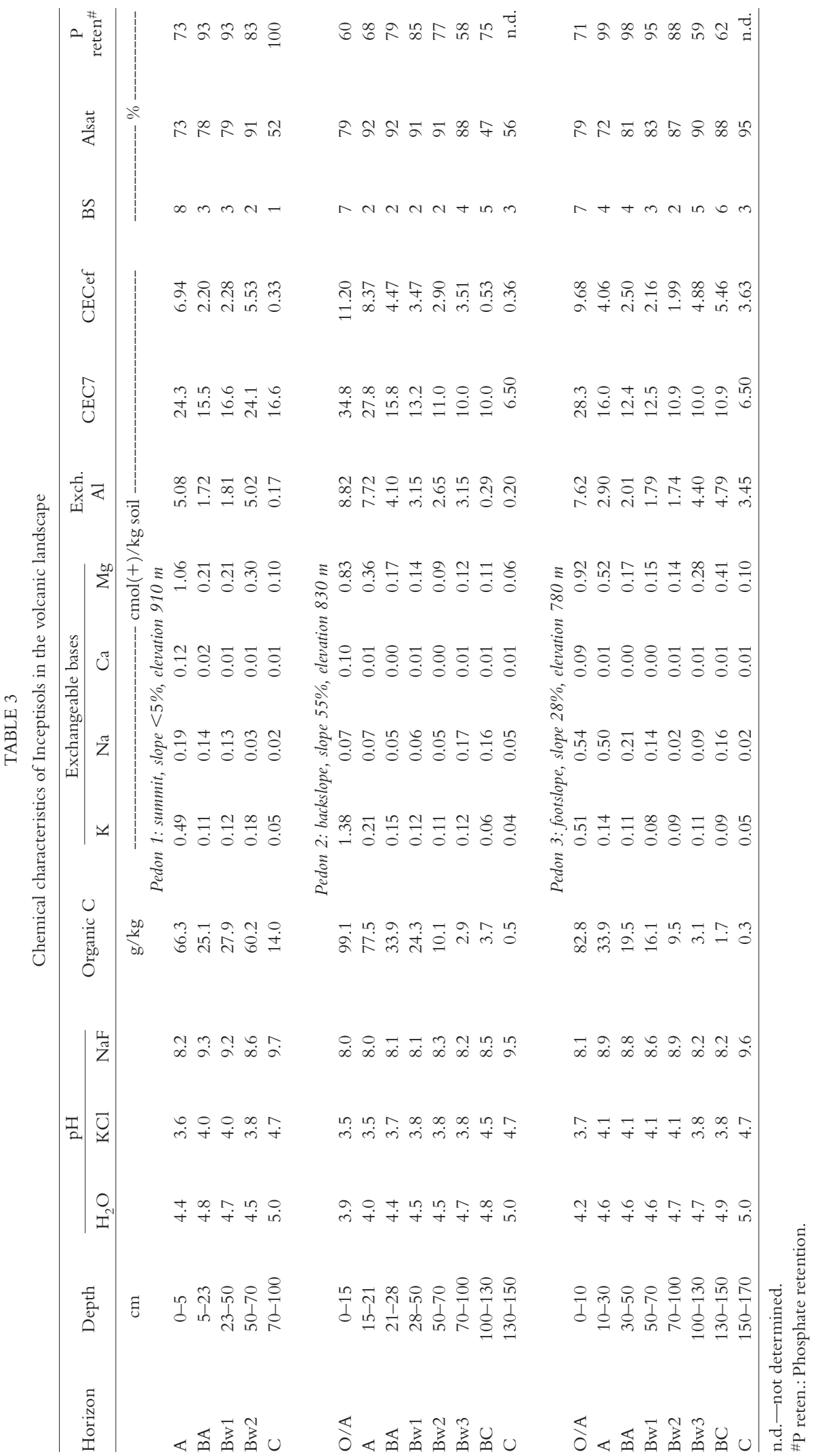




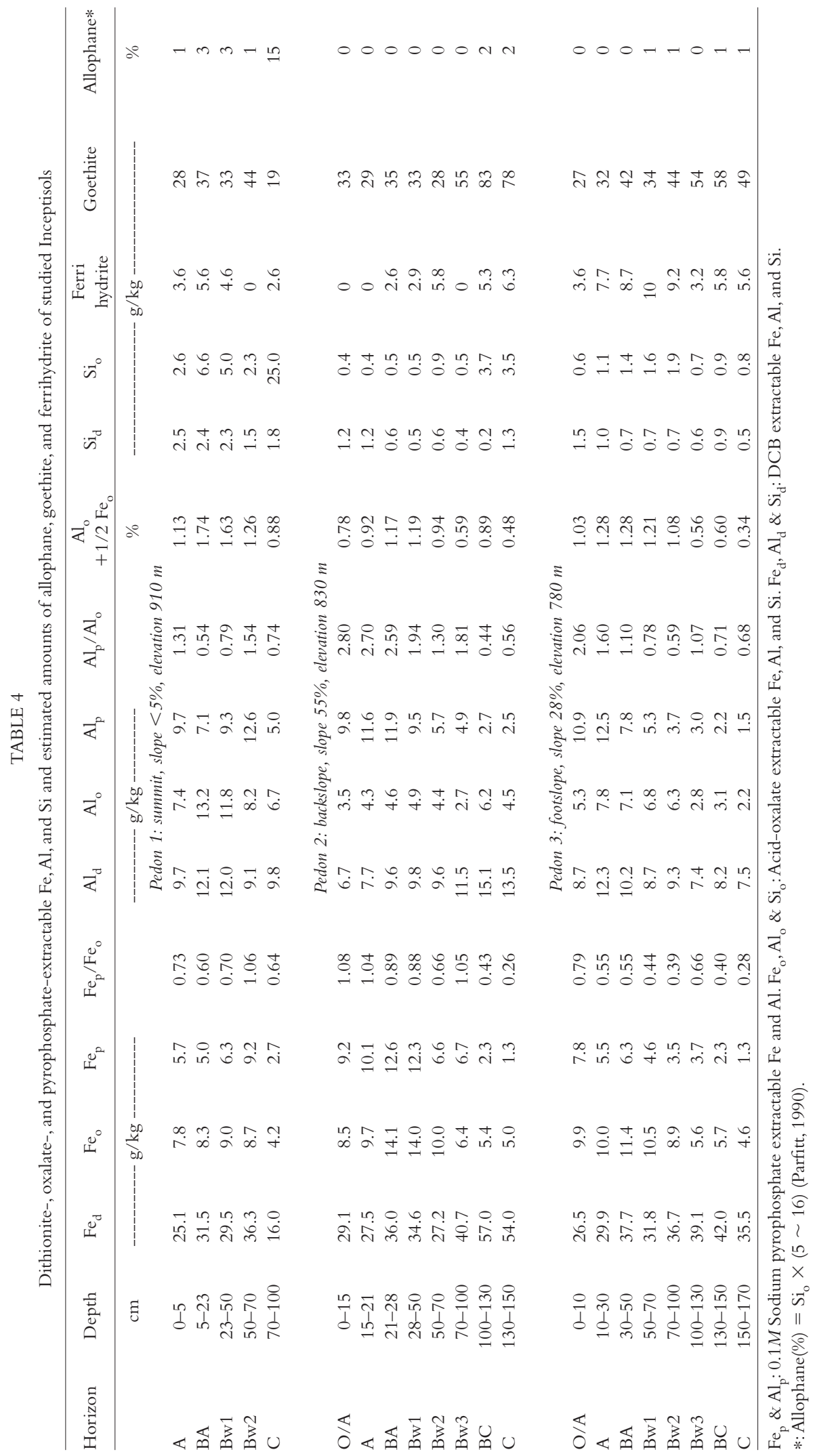


TABLE 5

Relative abundance of minerals in the sand fraction $(2000-50 \mu \mathrm{m})$ by XRD analysis

\begin{tabular}{|c|c|c|c|c|c|c|c|}
\hline Horizon & Depth $(\mathrm{cm})$ & $\mathrm{Qz}$ & Gib & $\mathrm{Cr}$ & Py & $\mathrm{Am}$ & $\mathrm{Fd}$ \\
\hline \multicolumn{8}{|c|}{ Pedon 1: summit, slope $<5 \%$, elevation $910 \mathrm{~m}$} \\
\hline A & $0-5$ & +++ & +++ & + & + & + & + \\
\hline BA & $5-23$ & ++ & +++ & + & + & + & + \\
\hline Bw1 & $23-50$ & ++ & ++ & + & ++ & ++ & + \\
\hline Bw2 & $50-70$ & ++ & ++ & ++ & ++ & + & ++ \\
\hline $\mathrm{C}$ & $70-100$ & ++ & +++ & ++ & + & ++ & +++ \\
\hline \multicolumn{8}{|c|}{ Pedon 2: backslope, slope $55 \%$, elevation $830 \mathrm{~m}$} \\
\hline $\mathrm{O} / \mathrm{A}$ & $0-15$ & ++++ & ++ & + & + & + & - \\
\hline A & $15-21$ & ++++ & +++ & - & + & - & + \\
\hline BA & $21-28$ & ++++ & ++ & + & - & + & + \\
\hline Bw1 & $28-50$ & ++++ & +++ & + & + & - & + \\
\hline Bw2 & $50-70$ & +++ & +++ & + & + & ++ & + \\
\hline Bw3 & $70-100$ & +++ & +++ & - & + & + & ++ \\
\hline $\mathrm{BC}$ & $100-130$ & ++ & +++ & ++ & + & + & ++ \\
\hline $\mathrm{C}$ & $130-150$ & ++ & +++ & ++ & ++ & ++ & +++ \\
\hline \multicolumn{8}{|c|}{ Pedon 3: footslope, slope $28 \%$, elevation $780 \mathrm{~m}$} \\
\hline $\mathrm{O} / \mathrm{A}$ & $0-10$ & ++++ & ++ & - & + & - & - \\
\hline A & $10-30$ & ++++ & ++ & - & ++ & - & + \\
\hline BA & $30-50$ & ++++ & ++ & - & + & + & ++ \\
\hline Bw1 & $50-70$ & +++ & ++ & + & - & + & + \\
\hline Bw2 & $70-100$ & ++++ & +++ & - & + & + & + \\
\hline Bw3 & $100-130$ & +++ & +++ & + & + & + & + \\
\hline BC & $130-150$ & +++ & +++ & + & + & + & ++ \\
\hline $\mathrm{C}$ & $150-170$ & ++ & +++ & ++ & ++ & ++ & +++ \\
\hline
\end{tabular}

Symbols:

Qz: quartz, Gib: gibbsite, Cr: cristobalite, Py: pyroxene, Am: amphibole, Fd: feldspar.

- : non-detectable, $+;<10 \%,++: 10-25 \%,+++: 25-50 \%,++++:>50 \%$.

(Table 6). Minor amounts of cristobalite and quartz were also observed in the clay fraction. Gibbsite in the clays, like that in the sand fraction, probably comes from the weathering of feldspar. Kaolinite, on the other hand, may have come from kaolinitization of halloysite (Jahn, 1988) or from direct crystallization of kaolinite as shown by Sieffermann and Millot (1969). The minor amounts of layer silicates (2:1 type) probably formed in cracks and pores in the andesite, where saturated weathering solutions could have remained for a long period of time thereby enhancing the formation of such clay minerals, as has been proposed by Jahn and Asio (1998) and Chen et al. (1999).

\section{Factors and Pedogenic Processes}

The young nature of Inceptisols has been ascribed to geologically young parent material or landscapes and to environmental conditions that inhibit soil formation (Foss et al., 1983; ISSS Working Group RB, 1998). Inasmuch as the en- vironmental characteristics of the volcanic landscape studied such as the very high rainfall, good drainage, easily weatherable rocks, forest, and grass vegetation, are generally favorable to soil formation, the occurrence of the Inceptisols at this study site may be due largely to the moderate age of the parent material. This means that the amount of time during which soil-forming processes have acted on the parent material is enough to produce a slightly developed soil. However, because older soils, particularly Ultisols, are common in the lower and older mountain slopes in our study site, we hypothesize that the Inceptisols will continue developing into Ultisols.

Buol et al. (1997) noted that Inceptisols are relatively young and that they show the initiation of many pedogenic processes. Our results lead us to consider that the following pedogenic processes are occurring significantly or have occurred in the Inceptisols in our study area: structure formation, loss of bases and acidification, braunification (brown color development), weathering and clay 
TABLE 6

Relative abundance of clay, aluminum hydroxide, and silicate oxides minerals in the clay fraction $(<2 \mu \mathrm{m})$ of the studied soils

\begin{tabular}{|c|c|c|c|c|c|c|c|c|}
\hline Horizon & Depth $(\mathrm{cm})$ & Ill & Chl & HIV & Kao & Gib & $\mathrm{Cr}$ & Qz \\
\hline \multicolumn{9}{|c|}{ Pedon 1: summit, slope $<5 \%$, elevation $910 \mathrm{~m}$} \\
\hline A & $0-5$ & ++ & + & ++ & ++ & +++ & ++ & + \\
\hline BA & $5-12$ & + & ++ & ++ & ++ & +++ & + & + \\
\hline Bw1 & $23-50$ & + & ++ & ++ & ++ & ++ & + & + \\
\hline Bw2 & $50-70$ & ++ & + & ++ & ++ & +++ & + & + \\
\hline $\mathrm{C}$ & $70-100$ & + & + & + & ++ & +++ & ++ & + \\
\hline \multicolumn{9}{|c|}{ Pedon 2: backslope, slope 55\%, elevation $830 \mathrm{~m}$} \\
\hline $\mathrm{O} / \mathrm{A}$ & $0-15$ & ++ & ++ & ++ & +++ & ++ & + & + \\
\hline A & $15-21$ & ++ & ++ & ++ & +++ & ++ & + & + \\
\hline BA & $21-28$ & ++ & ++ & ++ & +++ & ++ & + & + \\
\hline Bw1 & $28-50$ & ++ & ++ & ++ & +++ & ++ & + & + \\
\hline Bw2 & $50-70$ & ++ & ++ & ++ & +++ & ++ & + & + \\
\hline Bw3 & $70-100$ & ++ & ++ & ++ & +++ & ++ & + & + \\
\hline $\mathrm{BC}$ & $100-130$ & ++ & + & + & ++ & ++ & ++ & + \\
\hline C & $130-150$ & + & + & + & ++ & ++ & + & + \\
\hline \multicolumn{9}{|c|}{ Pedon 3: footslope, slope 28\%, elevation $780 \mathrm{~m}$} \\
\hline $\mathrm{O} / \mathrm{A}$ & $0-10$ & + & ++ & ++ & +++ & ++ & + & + \\
\hline A & $10-30$ & ++ & ++ & ++ & +++ & ++ & + & + \\
\hline BA & $30-50$ & ++ & ++ & ++ & ++ & +++ & + & + \\
\hline Bw1 & $50-70$ & ++ & ++ & ++ & +++ & ++ & + & + \\
\hline Bw2 & $70-100$ & ++ & ++ & ++ & +++ & +++ & + & + \\
\hline Bw3 & $100-130$ & ++ & ++ & ++ & +++ & ++ & + & + \\
\hline $\mathrm{BC}$ & $130-150$ & ++ & + & ++ & ++ & +++ & ++ & + \\
\hline $\mathrm{C}$ & $150-170$ & + & + & + & + & +++ & + & + \\
\hline
\end{tabular}

Symbols:

Ill: illite, Kao: kaolinite, Gib: gibbsite, Cr: cristobalite, Chl: chlorite, HIV: hydroxy-interlayered vermiculite, Qz: quartz.

$+:<10 \%,++: 10-25 \%,+++: 25-50 \%,++++:>50 \%$.

mineral formation, organic matter accumulation, and bioturbation. Structure formation is indicated by the moderate angular blocky structure exhibited by the cambic (Bw) horizon. Loss of bases and acidification are reflected by the low base saturation, low amount of exchangeable bases, low $\mathrm{pH}$, and high aluminum saturation. Loss of bases and acidification were probably enhanced by the very high rainfall and the very good drainage conditions in the study area, which caused intensive leaching. Braunification is the process of brown color development as a result of secondary $\mathrm{Fe}$ oxide formation as indicated by substantial amounts of $\mathrm{Fe}_{\mathrm{d}}$ and $\mathrm{Fe}_{\mathrm{o}}$ (Blume and Schwertmann, 1969; Ugolini, 1986; Blume, 1988; Chen et al., 1999). Organic matter accumulation is due to the recalcitrant metal-humus complexes, as indicated by considerable amounts of $\mathrm{Fe}_{\mathrm{p}}$ and $\mathrm{Al}_{\mathrm{p}}$, and by $\mathrm{P}$ deficiency and $\mathrm{Al}$ toxicity. The relatively temperate temperature (average 17 ${ }^{\circ} \mathrm{C}$ ) also contributes to organic matter accumulation. Bioturbation is particularly important for the formation of the high humus A horizon. This was indicated by abundant biopores and worm holes in the upper part of the pedons. Weathering appears to be rapid because of the easy weatherability of the volcanic pyroclastic (Asio and Chen, 1998) and is enhanced by the perhumid climate and good drainage of the area. This has resulted in the formation of the mixture of clay minerals such as kaolinite and 2:1 types. It has occurred or is occurring in the soils, resulting in the development of properties associated with Andisols such as low bulk density, high phosphate and water retention, and considerable amounts of aluminum associated with humus.

\section{Classification and Relation to Andisols}

All pedons are classified as Andic Dystrudepts, based on the USDA Soil Taxonomy (Soil Survey Staff, 1998), and as Dystric Cambisols, according to the World Reference Base (ISSS Working Group RB, 1998; FAO, 1998). All three soils failed the $\mathrm{Al}_{\mathrm{o}}+1 / 2 \mathrm{Fe}_{\mathrm{o}}(\%)$ criterion for the Andic 
soil property, although pedons 1 and 3 met the criteria of bulk density and phosphate retention. Pedon 2 also showed low bulk density and high $\mathrm{P}$ retention but was below the limit for the Andic property of Soil Taxonomy. However, it satisfied the phosphate retention criterion of the World Reference Base. Therefore, the data reveal that the soils are pedogenically closely related to the Andisols that are widespread in the volcanic landscape investigated in northern Taiwan. These Inceptisols seem to be more developed than the Andisols in the area that we studied earlier (Huang and Chen, 1990; Chen and Huang, 1991; Chen et al., 1999). This degree of development is based on the degree of weathering, amount and type of clay, soil structure, and consistency. Therefore, we hypothesize that these Inceptisols have developed from Andisols and that they probably followed the Entisol $\rightarrow$ Andisol $\rightarrow$ Inceptisol formation sequence that has also been observed in New Zealand (Parfitt et al., 1983) and the Philippines (Otsuka et al., 1988).

\section{CONCLUSIONS}

Formation of the Inceptisols was caused largely by the moderate weathering stage of the pyroclastic material, not by any environmental factors that inhibit soil formation. The soil formation was relatively fast due to the easy weatherability of the pyroclastic materials, perhumid climate, and good drainage of the volcanic landscape. The Inceptisols seem to have developed from earlier formed Andisols, as indicated by the presence of Andic features such as low bulk density, high water and phosphate retention, and a considerable amount of aluminum associated with humus. Therefore, the sequence of soil formation was likely Entisol $\rightarrow$ Andisol $\rightarrow$ Inceptisol. The most important soil-forming processes that have occurred in these soils include structure formation, loss of bases and acidification, brunification, bioturbation, organic matter accumulation, weathering, and clay mineral formation.

\section{ACKNOWLEDGEMENT}

The authors are grateful to the National Science Council, Republic of China, for the financial support that made this research possible.

\section{REFERENCES}

Asio, V. B. 1996. Characteristics, Weathering, Formation and Degradation of Soils from Volcanic Rocks in Leyte, Philippines. Hohenheimer Bodenkundliche Hefte, vol. 33, Stuttgart, Germany.

Asio, V. B., and Z. S. Chen. 1998. Study of andesite weathering in northern Taiwan using micromor- phological approaches. Taiwan J. For. Sci. 13: 259-269

Blakemore, L. C., P. L. Searle, and B. K. Daly. 1981. Methods for chemical analysis of soils. New Zealand Soil Bureau Scientific Report 10A, Lower Hutt, N.Z.

Blume, H. P. 1988. The fate of iron during soil formation in humid-temperate environment. In Iron in the Soil and Clay Minerals. J. W. Stucki, B. A. Goodman, and U. Schwertmann (eds.). NATO ASI Series, Series C: Mathematical and Physical Sciences, Vol. 217, pp. 749-777.

Blume, H. P., and U. Schwertmann. 1969. Genetic evaluation of profile distribution of aluminum, iron and manganese oxides. Soil Sci. Soc. Am. Proc. 33:438-444.

Buol, S. W., F. D. Hole, R. J. McCracken, and R. J. Southard. 1997. Soil Genesis and Classification, 4th Ed. Iowa State University Press, Ames, IA.

Chen, C. H. 1990. Igneous Rocks of Taiwan. Central Geology Institute, Ministry of Economics, R.O.C. (in Chinese with English summary).

Chen, Z. S., and J. H. Huang. 1991. Characteristics and clay minerals of Andisols in northeastern Chihsing Mountain, Taiwan. J. Chin. Agric. Chem. Soc. 29:415-426 (in Chinese with English summary).

Chen, Z. S., V. B. Asio, and D. F. Yi. 1999. Characteristics and genesis of volcanic soils along a toposequence under a subtropical climate in Taiwan. Soil Sci. 164:510-525

Childs, C. W., N. Matsue, and N. Yoshinaga. 1991. Ferrihydrite in volcanic ash soils of Japan. Soil Sci. Plant Nutr. 37:299-311.

Dahlgren, R. A., J. P. Dragoo, and F. C. Ugolini. 1997. Weathering of Mt. St. Helens tephra under a cryicudic climatic regime. Soil Sci. Soc. Am. J. 61: 1519-1525.

FAO. 1998. World Reference Base for Soil Resources. World Soil Resources Report No. 84. Rome, Italy.

Foss, J. E., F. R. Moormann and S. Rieger. 1983. Inceptisols. In Pedogenesis and Soil Taxonomy, Vol. II. Soil Orders. L.P. Wilding, N.E. Smeck, and G.F. Hall (eds.). Elsevier, Amsterdam, pp. 355-378.

Hamazaki, T., and E. P. Paningbatan, Jr. 1988. Procedures for soil analysis. Dept. Soil Sci., Univ. of the Philippines, Los Banos, and Trop. Agric. Res. Center, Japan.

Hewitt, A. E., and J. E. Witty. 1988. Andisol transitions with other soils, particularly Inceptisols. In Proc. 9th Int. Soil Classification Workshop. D.I. Kinloch, S. Shoji, F.H. Beinroth, and H. Eswaran (eds.). Japanese Committee of the 9th Int. Soil Classification Workshop for SMSS, Washington, DC, pp. 233-241

Huang, J. H., and Z. S. Chen. 1990. Characteristics, genesis and classification of two Andisols in Chihsingshan Mountain area, northern Taiwan. J. Chin. Agric. Chem. Soc. 28:135-147. (in Chinese with English summary).

ISSS Working Group RB. 1998. World Reference Base for Soil Resources: Introduction.J.A. Deckers, F. D. Nachtergaele, and O. C. Spaargaren (eds.). ISSS-ISRIC-FAO, Acco, Leuven. 
Jahn, R. 1988. Soils of Lanzarote: Occurrence, genesis and characteristics of soils from volcanic rocks in the semi-arid climate of Lanzarote (Canary Islands). Hohenheimer Arbeiten, Ulmer Verlag, Stuttgart, Germany (in German with English Summary)

Jahn, R., and V. B. Asio. 1998. Soils of the tropical forests of Leyte, Philippines. 1: Weathering, soil characteristics, classification and site qualities. In Soils of Tropical Forest Ecosystems. A. Schulte and D. Ruhiyat (eds.). Springer-Verlag, Berlin, pp. 29-36.

Jenny, H. 1941. Factors of Soil Formation. McGrawHill Book Co., New York.

Klute, A. 1986. Water retention: Laboratory methods. In Methods of Soil Analysis, Part 1, 2nd Ed. Physical and Mineralogical Methods, A. Klute (ed.). Agron. Monogr. No. 9. ASA and SSSA, Madison, WI, pp. 635-660.

Mehra, O. P., and M. L. Jackson. 1960. Iron oxide removal from soils and clays by a dithionite-citrate system buffered with sodium bicarbonate. Clays Clay Miner. 7:317-327.

McKeague, J. A. 1967. An evaluation of $0.1 \mathrm{M}$ pyrophosphate and pyrophosphate-dithionite in comparison with oxalate as extractants of the accumulation products in Podzols and some other soils. Can. J. Soil Sci. 47: 95-99.

Miehlich, G. 1991. Chronosequences of volcanic ash soils. Hamburger Bodenkundliche Arbeiten, Vol. 15. Hamburg, Germany.

Nelson, D. W., and L. E. Sommers. 1982. Total carbon, organic carbon and organic matter. In Methods of Soil Analysis, Part 2. Chemical and Microbiological Properties, 2nd Ed. A.L. Page et al. (eds.). ASA, Madison, WI, pp. 539-594.

Otsuka, H., A. A. Briones, N. P. Daquiado, and F. A. Evangelio. 1988. Characteristics and genesis of volcanic ash soils in the Philippines. Tech. Bull. No. 24, TAR C, Japan.

Parfitt, R. L. 1990. Allophane in New Zealand-a review. Aust. J. Soil Res. 28:343-360

Parfitt, R. L., and J. M. Kimble. 1989. Conditions for formation of allophane. Soil Sci. Soc. Am. J. 53: 971-977.
Parfitt, R. L., and A. D. Wilson. 1985. Estimation of allophane and halloysite in three sequences of volcanic soils, New Zealand. In Volcanic Soils. E. Fernandez-Caldas and D.H. Yaalon (eds.). Catena Suppl. 7, Catena-Verlag, Cremlingen, Germany, pp. 1-8.

Parfitt, R. L., M. Russell, and G. E. Orbell. 1983. Weathering sequence of soils from volcanic ash involving allophane and halloysite, New Zealand. Geoderma 29:41-57

Schlichting, E., H. P. Blume, and K. Stahr. 1995. Bodenkundliches Praktikum, 2nd Ed. Blackwell, Berlin.

Schwertmann, U. 1964. Differenzierung der Eisenoxide des Bodens durch Extraktion mit Ammoniumoxalat-Loesung. Z. Pflanzenernaehr. Dueng. Bodenkd. 105:194-202.

Shoji, S., M. Nanzyo, and R. A. Dahlgren. 1993. Volcanic Ash Soils: Genesis, Properties and Utilization. Developments in Soil Sci. No. 21. Elsevier, Amsterdam.

Siefferman, G., and G. Millot. 1969. Equatorial and tropical weathering of recent basalts from Cameroon: Allophane, halloysite, metahalloysite, kaolinite and gibbsite. Proc. Int. Clay Conf. Jpn. 1:417-429

Soil Survey Staff. 1993. Soil Survey Manual. USDA Handbook No. 18. U.S. Govt. Printing Office, Washington, DC.

Soil Survey Staff. 1998. Keys to Soil Taxonomy, 8th Ed. USDA-NRCS, Washington, DC.

Thomas, G. W. 1982. Exchangeable cations. In Methods of Soil Analysis, Part 2. Chemical and Microbiological Properties, 2nd Ed. A.L. Page et al. (eds.). ASA and SSSA, Madison, WI, pp. 159-165.

Torrent, J., and J. Benayas. 1977. Origin of gibbsite in a weathering profile from granite in west-central Spain. Geoderma 19:37-49.

Ugolini, F. C. 1986. Pedogenic zonation in the well drained soils of the Arctic regions. Quat. Res. 26: 100-120.

Whittig, L. D., and W. R. Allardice. 1982. X-ray diffraction techniques. In Methods of Soil Analysis, Part 1, 2nd Ed. Physical and Mineralogical Methods. A. Klute (ed.). Agron. Monogr. No. 9. ASA and SSSA, Madison, WI, pp. 331-359. 